\title{
Trinitologia picta na przykładzie polichromii w kościele pod wezwaniem Nawiedzenia NMP w Kaliszu Program badań
}

Pomimo iż arcybiskup gnieźnieński Jan Gruszczyński osadził bernardynów w Kaliszu już w 1465 roku, poprzedzony drewnianym kościół murowany wzniesiono dopiero w pierwszej połowie XVII stulecia ${ }^{2}$. Jest on budowlą bez wież, jednonawową, pozbawioną na zewnątrz ozdób i architektonicznego detalu. Ma wyraźnie wyodrębnione, zamknięte wielobocznie prezbiterium, węższe i niższe od dwukrotnie dłuższej, czteroprzęsłowej nawy, ściany przeprute zakończonymi półkoliście wydłużonymi oknami i szkarpy uwydatniające czytelny, wewnętrzny podział na przęsła. W XVIII wieku fasadę kościoła przebudowano: dobudowując kruchtę i tworząc przedsionek, przysłonięto niższą kondygnację fasady. Znany jest też budowniczy świątyni. Był nim najprawdopodobniej bernardyn Wojciech Samborinus.

Mimo iż architektonicznie skromny, kaliski kościół pobernardyński intryguje bogatą dekoracją malarską (polichromie), którą od 1764 roku realizowali bernardyni: brat Walenty (Antoni) Żebrowski (w prezbiterium i nawie) oraz jego współpracownicy - Paschalis Wołos, uczeń W. Żebrowskiego (w kruchcie),

\footnotetext{
1 Justyna Sprutta - dr, teolog i historyk (specjalizacje: teologia ikony i historia sztuki), magister filologii polskiej. Wykłada na Wydziale Teologicznym Uniwersytetu im. Adama Mickiewicza w Poznaniu, w Akademii im. Aleksandra Gieysztora w Pułtusku i w Prymasowskim Instytucie Kultury Chrześcijańskiej w Bydgoszczy. Jest bibliotekarką w Gminnej Bibliotece Publicznej w Sieroszewicach. Członkini Polskiego Instytutu Studiów nad Sztuką Świata i Poznańskiego Towarzystwa Przyjaciół Nauk; e-mail: justynasprutta@o2.pl. ORCID: 0000-0001-9949-9953.

${ }^{2}$ W 1919 roku kaliski kościół bernardynów przejęli jezuici. Do dzisiaj pozostaje w ich rękach. Od 1998 roku kościół jest sanktuarium Serca Jezusa Miłosiernego.
} 
i Wacław Porowski (w zakrystii). Owi artyści, P. Wołos i W. Porowski, tworzyli w kaliskim kościele polichromie w latach 1766-1785, czyli w czasach, kiedy to od 1760 roku gwardianem kościoła był ojciec Bonawentura Strzelecki, a od 1766 roku prowincjałem, fundator malowideł w zakrystii, a jego następcą ojciec Bernard Klinowski. W 1785 roku na polecenie ojca Idziego Kłąbczyńskiego ozdobiono polichromią kruchtę.

Wykonane przez W. Żebrowskiego w kaliskim kościele ${ }^{3}$ malowidła ścienne zaprojektował najprawdopodobniej ojciec Anzelm Kiełbasiewicz, jezuita i profesor teologii z Poznania, nadając zaplanowanym polichromiom głęboką, teologiczną wymowę, choć przypuszcza się również, że mógł on zaprojektować jedynie napisy towarzyszące malowidłom. Co więcej, A. Kiełbasiewicz miał być także twórcą programu ikonograficznego polichromii nieistniejącej obecnie już w zakrystii, wykonanej w 1766 roku przez W. Porowskiego, a zamalowanej podczas hitlerowskiej okupacji ${ }^{4}$.

O samym W. Żebrowskim wiadomo, że pochodził z Lubawy na Warmii. Wywodził się ze szlacheckiego rodu z Ziemi Łomżyńskiej, pieczętującego się herbem Jasieńczyk. Wstąpił do zakonu bernardynów w 1737 roku, a nowicjat odbył w Poznaniu, gdzie w dniu 16 września 1738 roku złożył profesję zakonną. Zmarł w dniu 15 maja 1765 roku. Okoliczności jego śmierci są niejasne. Przypuszczalnie spadł z rusztowania, chociaż pewniejsza jest jego śmierć wskutek nieszczęśliwego wypadku spowodowanego dwukrotnym wywróceniem się zaprzężonego w konie wozu w drodze prowadzącej z Poznania do Kalisza.

Artystycznie W. Żebrowski kształcił się, co wielce prawdopodobne, pod okiem brata Benedykta Mazurkiewicza, artysty z Lwowa, a także franciszkanina Adama Swacha, malarza z Poznania 5 . To właśnie w Poznaniu w 1737 roku rozpoczęła się malarska kariera W. Żebrowskiego. Pozostawił on po sobie nie tylko kaliskie polichromie, ale także malowidła w ówcześnie bernardyńskich kościołach w: Poznaniu, Kadynach, Wschowie, Skępem, Warcie, Ostrołęce, Warszawie oraz przypuszczalnie też w Owińskach, Ostrzeszowie i Łęczycy, mimo iż co do autorstwa łęczyckich malowideł (kościół pod wezwaniem Niepokalanego

${ }^{3}$ Szerzej o twórczości W. Żebrowskiego w kościele pobernardyńskim w Kaliszu: J. Sprutta, Barokowa polichromia kościoła pobernardyńskiego w Kaliszu, „Studia Franciszkańskie” t. XXVII (2017), s. 265-295. Por. J.A. Dymkowska-Francuz, Historia pobernardyńskiego zespolu klasztornego w Kaliszu (obecnie klasztor oo. Jezuitów), „Kalisia Nowa” (2007) nr 2-3-4, s. 8-9; A. Tabaka, Władca pędzla w habicie, „Kalisia Nowa” (2007), nr 2-3-4, s. 1.

${ }^{4}$ J.A. Dymkowska, Kościót pobernardyński (obecnie OO. Jezuitów), http://www.kalisz.info/ kosciol-jezuitow.html [dostęp 20.05.2021].

${ }^{5}$ A.E. Czerwińska, Adama Swacha portret własny - czyli kilka uwag o sygnaturach $i$ autoportretach barokowego artysty, s. 424 i s. 436, http://www.lad.pl/assets/czerwinska_swach.pdf [dostęp 16.05.2021]. Szerzej o życiu i artystycznej działalności brata Adama Swacha: por. T. Jank, Życie i twórczość malarska brata Adama Swacha (1668-1747), Kraków 2017. 
Poczęcia NMP) podejrzewa się również, że to nie W. Żebrowski był ich twórcą, ale nieznany z nazwiska artysta ze Śląska ${ }^{6}$.

Śledząc dokonania W. Żebrowskiego, można dopowiedzieć, że przed 1741 rokiem zakonnik ten wykonał malowidła na sklepieniu kościoła bernardynów w Ostrzeszowie (obecnie kościół przy klasztorze nazaretanek). W Kadynach niedaleko Elbląga tworzył w latach 1743-1744, a pomagał mu bernardyn - brat Antoni Słaboszewski. We Wschowie w 1745 roku wykonał z pomocą swego współpracownika, brata Liboriusza Staniszewskiego, malowidła na sklepieniu tamtejszego kościoła bernardyńskiego. Polichromię w Skępem realizował natomiast w latach 1750-1753 przy okazji koronacji słynącej cudami figury Matki Bożej Skępskiej. Na sklepieniu kościoła bernardynów w Warcie, w której działał w latach 1756-1761, umieścił po raz pierwszy swój autoportret. Ukazał siebie jako siedzącego przed sztalugami w momencie, gdy maluje obraz przedstawiający Matkę Bożą. Jest tutaj jeszcze stosunkowo młodym mężczyzną w przeciwieństwie do warszawskiego autoportretu z kościoła pod wezwaniem świętej Anny, gdzie wyobraził siebie w wieku między czterdziestym a pięćdziesiątym rokiem życia. Na sklepieniu kościoła bernardyńskiego w Ostrołęce namalował w latach 1762-1764 między innymi cztery pory roku (uszkodzone w 1989 roku przez pożar). W Łęczycy realizował polichromię w latach 1762-1763, czyniąc dominującą tematykę maryjną. W kościele pod wezwaniem świętej Anny w Warszawie działał artystycznie między 1747 a 1753 rokiem $^{7}$. Do Warszawy W. Żebrowskiego i jego warsztat sprowadził ojciec Mateusz Roznerski. Zgodnie z sugestią M. Roznerskiego, autora programu teologiczno-ikonograficznego, W. Żebrowski ukazał w absydzie warszawskiego kościoła pod wezwaniem świętej Anny, podobnie jak w kaliskim kościele, Matkę Bożą Anielską, której towarzyszy w prezbiterium święty Franciszek (w świątyni w Kaliszu wyobrażony jest w nawie). Zresztą zakonna rodzina franciszkańska, do której przecież należeli i bernardyni, szczególną czcią darzyła Maryję jako Matkę Bożą Anielską, widniejącą, między innymi na kaliskim malowidle, w otoczeniu reprezentantów chórów anielskich. Tematem tym jest apoteoza Matki Bożej Anielskiej patronującej polskim bernardynom ${ }^{8}$. Na sklepieniach prezbiterium i nawy w warszawskim kościele W. Żebrowski przedstawił ponadto pięcioobrazowy cykl zawierający sceny z życia świętej Anny (w nawie) i jej córki Maryi (w apsydzie), na

${ }^{6}$ W autorstwo W. Żebrowskiego wątpi J. Kowalczyk. Por. J. Kowalczyk, Andrea Pozzo a późny barok w Polsce. Freski sklepienne, cz. 2, „Biuletyn Historii Sztuki” (1975) nr 4, s. 338.

${ }^{7}$ Osiemnastowieczna dekoracja warszawskiego kościoła pod wezwaniem świętej Anny nie dotrwała w pierwotnej formie do współczesności, ponieważ w XIX wieku przeszła trzy renowacje.

${ }^{8}$ R. Zdziarska, Malowidła ścienne $w$ kościele św. Anny $w$ Warszawie $i$ ich konserwacja, „Ochrona Zabytków” (1989) nr 3-4, s. 222. 
żaglach symbole zapowiadające Wcielenie, pod oknami sybille i profetów z kartuszami ze starotestamentalnymi proroctwami, natomiast w kaplicy epizody związane z bernardynem - błogosławionym Ładysławem z Gielniowa, chociażby mające miejsce w dniu 13 kwietnia 1572 roku podniesienie jego szczątków i modlitwę księżnej Anny Mazowieckiej. Przez osiem lat W. Żebrowski dekorował wraz z czterema pomocnikami warszawski kościół i kaplicę. Umieścił też tutaj autoportret, o czym już wspomniano, oraz wizerunki pomocników, mianowicie $\mathrm{w}$ gronie rodzimych świętych w kopule kaplicy pod wezwaniem świętego Ładysława. Sportretował siebie z paletą i pędzlami, razem ze swoimi pomocnikami: wymienionym już Liboriuszem Staniszewskim, Michałem Thiemem, Piotrem Chawałkiewiczem (zapewne początkującym pomocnikiem malarskim) i wyłaniającym się zza pleców mistrza, również wcześniej wspomnianym, Antonim Słaboszewskim, o którym wiadomo, że zmarł w 1744 roku w Kaliszu, najprawdopodobniej młodo, oraz że był malarzem sztalugowym i współpracownikiem W. Żebrowskiego w Kadynach. Walenty Żebrowski ukazał siebie $\mathrm{z}$ paletą i pędzlami jako stojącego w centrum grupy, w pozycji en trois quatrs, gdy prowadzi dyskurs z dwoma zakonnikami, z których jeden wskazuje na klęczącego P. Chawałkiewicza. Oblicze W. Żebrowskiego cechują wyraziste rysy, duży nos, wydatna broda oraz długie, proste, przycięte nad czołem włosy opadające na kaptur habitu?.

Artystyczną twórczość W. Żebrowskiego można postrzegać jako iluzjonistyczną, stylistycznie jednolitą, o bogatej tematyce, skomplikowanej, obfitującej w symbole, metafory i alegorie, podporządkowaną ogólnym podziałom architektonicznym wnętrza. Talent $\mathrm{i}$ inwencja owego bernardyna ujawniły się w szczególności w budowaniu scen, portretowym ujęciu postaci oraz w dekoracji rocaille'owo-florystycznej. Zasłynął zwłaszcza jako pejzażysta. Spod jego pędzla wyłoniły się odrealnione pejzaże z dynamicznymi, fantazyjnymi, rzeźbiarskimi i architektonicznymi bryłami, wzbogacone ornamentem rocaille oraz skomplikowanymi symbolami i alegoriami. W związku z tym, iż rzadko w sakralnym malarstwie baroku widniały w pejzażach ruiny i fantastyczna architektura, przypuszcza się, że W. Żebrowski mógł przed wstąpieniem do zakonu bernardynów realizować nieznane bliżej, pałacowe dekoracje ${ }^{10}$. Piętą achillesową W. Żebrowskiego okazały się: iluzjonistyczna architektura, gdyż nie znał dobrze praw perspektywy oraz linearność w przedstawianiu ciała. Był on nato-

${ }^{9}$ Por. tamże, s. 217, 219-220. Por. A. Mulczyńska-Pawlak, Malarska działalność Walentego Żebrowskiego, „Studia Muzealne” (1968) nr 6, s. 113-118; M. Witwińska, Dzieje warszawskiej polichromii Walentego Żebrowskiego, „Biuletyn Historii Sztuki” (2006) nr 1, s. 59-94; M. Karpowicz, Abstrakcja i surrealizm w Warszawie XVIII w., w: tenże, Piękne nieznajome. Warszawskie zabytki XVII i XVIII wieku, Warszawa 1986, s. 330-344.

${ }^{10}$ R. Zdziarska, Malowidła ścienne w kościele św. Anny w Warszawie i ich konserwacja, s. 221. 
miast znamienitym kolorystą. Tworzył, na przykład w kościele pod wezwaniem świętej Anny w Warszawie, pejzaże, stosując - jako dominujące - kolory: niebieski, różowy i jasnozielony, dzięki czemu ogólna tonacja malowideł w warszawskiej świątyni jest delikatna, pastelowa, świetlista. Cechowało go również rozwinięte poczucie dekoracyjności, ujawniające się chociażby w umiejętnym stosowaniu ornamentyki i zdobniczych motywów. Tworzył fantazyjne elementy architektoniczne i ornamentalne, najczęściej kompilując i trawestując rozmaite motywy dostarczane przez grafiki ornamentalne Meissoniera, de Cuvilliésa i augsburskich artystów. Kanwą kompozycji i scen figuralnych, alegorycznych i emblematów, uczynił siedemnasto- i osiemnastowieczną grafikę dewocyjną. Faworyzowanym przez W. Żebrowskiego motywem, także zdobniczym, była delikatnie namalowana róża ${ }^{11}$. Następująco o wykonanej przez niego warszawskiej polichromii pisze Romana Zdziarska:

Dzieło Żebrowskiego nie jest dynamiczne, nie ma też w nim ekstazy cechującej wiele kompozycji z tej epoki. Jest to malarstwo pełne powietrza, światła, narracyjne, odznaczające się rokokową lekkością i delikatnością o cechach typowych dla polskiego warsztatu bernardyńskiego, dla którego dokumentacja teologiczno-ikonograficzna i historyczna miały większe znaczenie niż zagadnienia formalne. W niektórych partiach dekoracji architektonicznych (np. fryz i gurty) przejawia zainteresowanie formą klasycyzującą, ma więc w sobie również coś $\mathrm{z}$ widzenia „przełomowego”, wychodzącego nieśmiałym krokiem poza rokoko ${ }^{12}$.

${ }^{11} \mathrm{O}$ twórczości W. Żebrowskiego: por. M. Witwińska, Ostrotęcka polichromia Walentego Żebrowskiego, „Biuletyn Historii Sztuki” (1970) nr 3-4, s. 255; S.B. Tomczak, Biblioteka Główna Prowincji św. Franciszka z Asyżu zakonu Braci Mniejszych w Poznaniu, „Forum Bibliotek Medycznych" (2017) nr 1, s. 298; O.R. Jusiak, Bernardyńskie sanktuaria w Polsce, file://C:/Users/ PC/Downloads/Oktawian_Roman_Jusiak_OFM_2005_Bernardynskie_sanktuaria_w_Polsce $\% 20$ (1).pdf, s. 292 [dostęp 16.05.2021]; A. Mulczyńska-Pawlak, Malarska działalność Walentego Żebrowskiego, s. 113-118; M. Witwińska, Polichromia dwóch Trójc w kościele p.w. św. Józefa we Wschowie, „Ochrona Zabytków” (1999) nr 3, s. 273; S. Szymański, Dzieje klasztoru pobernardyńskiego w Kaliszu, obecnie jezuitów, w: 400 lat konsekracji pobernardyńskiego kościoła jezuitów w Kaliszu, red. J. Kacprzyk, A. Jacyniak, Kalisz 2007, s. 52; M. Walczak, Architektoniczna perta Kalisza. [Kościót i klasztor księży jezuitów w Kaliszu], „Studia Pedagogiczno-Artystyczne” t. III (2003), s. 17-27; P. Jaksim-Kirejczyk, Pierwowzory graficzne dziewięciu chórów anielskich na freskach Walentego Żebrowskiego w Warcie, w: Inspiracje grafikg europejska w sztuce polskiej. [Czasy nowożytne], red. K. Moisan-Jabłońska, K. Ponińska, Warszawa 2010, s. 160; E. Poniedziałek, M. Walczak, Materialny i duchowy wymiar obecności Zakonu Jezuitów w Kaliszu, w: Dziedzictwo kulturowe Miasta Kalisza i regionu poludniowej Wielkopolski, red. S. Kowalska, Poznań-Kalisz 2013, s. 18; M. Kurzej, Ikonografia malowidet w zakrystii (tzw. skarbcu) kościoła Dominikanów w Krakowie, w: Sztuka w kręgu krakowskich dominikanów, red. A. Markiewicz, M. Szyma, M. Walczak, Kraków 2013, s. 797.

${ }^{12}$ R. Zdziarska, Malowidła ścienne w kościele św. Anny w Warszawie i ich konserwacja, s. 222. 
Sceny figuralne, alegorie i emblematy, także w Kaliszu, W. Żebrowski dopełniał stosownymi wersami zaczerpniętymi, na przykład z Pisma Świętego, lecz nie tylko z Biblii, najczęściej stanowiącymi komentarz do malowideł, na przykład w Ostrołęce biblijne, łacińskie wersy umożliwiają stosowną interpretację treści polichromii. Również tutaj malowidła obfitują w motyw róży, uwydatniając iluzjonistyczną architekturę. Zarówno do stylu chociażby warszawskich, jak i kaliskich malowideł może odnosić się następująca wypowiedź R. Zdziarskiej:

Jego wkład do późnego baroku to nieokiełznana fantazja, która zachowała szacunek dla architektury, wypowiadający się w podkreślaniu gurtów, fryzu, podniebień łuków kolebkowych spokojną dekoracją linearną, zaakcentowaniu filarów iluzjonistycznymi pilastrami, stanowiącym antytezę w stosunku do wibrujących mięsistych splotów liściasto-rocaille'owych, którym towarzyszą zazwyczaj delikatnie malowane róże, ulubiony kwiat artysty ${ }^{13}$.

Zakon okazał wdzięczność za artystyczne zasługi W. Żebrowskiemu, dwukrotnie wpisując jego nazwisko do ksiąg bernardyńskich i wymieniając przy tym jego malarskie prace. Takie wyróżnienie przysługiwało jedynie wybitnym bernardynom. Szerszy wpis głosi:

Frater Valentinus Żebrowski laicus pictor optimus et Religiosus exemplaris, laboriosissimus, qui ecclesiam Ovenesensem Virginem cistercium, Nostras: Wschoviensem chorum et organa ac ecclesiam Posnaniensem, totam ecclesiam Varsaviensem, altaria, chorum et sacristiam, Ecclesiam Ostromencensem, chorum et altariam Calisiensem totam ecclesiam altariam, chorum et sacristiam jucundissimo depinxit penicillo. Cadens ex architecturas pectus fregit et oscubuit Callisy d. 15 May.

Zgodnie z tym wpisem W. Żebrowski był między innymi „malarzem najznakomitszym”, który polichromie „namalował najwdzięczniejszym pędzlem”"14.

W Kaliszu W. Żebrowski tworzył w latach 1764-1765. Także tutaj nie naśladował gotowych wzorników. W jego kaliskiej polichromii zwraca uwagę bardzo często powtarzający się motyw „trójki”. Pomysł jej rozmieszczenia jako symbolu wyszedł najprawdopodobniej od A. Kiełbasińskiego, o czym już zresztą wspomniano. Niewiele też wiadomo o innych dokonaniach tego jezuity i nie wiadomo także, czym inspirował się, decydując o kaliskim projekcie i go tworząc, czyli na jakiej teologicznej i intelektualnej bazie postanowił nadać taki a nie inny kształt swemu projektowi, w którym liczba trzy odegrała niebaga-

\footnotetext{
13 Tamże.

14 Tamże, s. 217.
} 
telną rolę. W tej kwestii można również postawić domagające się odpowiedzi w ramach dalszych badań pytanie, czy klucz „trójkowy” ma analogie wśród malarskich dekoracji z połowy XVIII wieku, dekoracji w rodzimych kościołach bernardyńskich? Kaliski motyw „trójki” jest tu jedynie przyczynkiem i zachętą do takich badań. Jeśli natomiast motyw ten nie ma analogii, warto wtedy odpowiedzieć na pytanie, dlaczego Kalisz jest tutaj wyjątkiem?

$\mathrm{Z}$ pewnością autor programu (lub samych napisów) zalecił zilustrowanie dogmatu o Trójcy Świętej. Kaliskie malowidła ukazują jej dwa wymiary istnienia i udzielania się: ad extra i ad intra. Być może też pomysłodawca zamierzał uwypuklić wyjątkowość tej liczby uchodzącej przecież za świętą nie tylko w chrześcijańskiej tradycji ${ }^{15}$. Symbolika cyfry „trzy” pojawia się w kaliskim kościele wielokrotnie, ale tylko w tych partiach malowideł, które łączone są z W. Żebrowskim.

O obecności „trójki” można już mówić, choć skromnie, w przypadku malowideł zdobiących poświęcone Matce Bożej Anielskiej prezbiterium. Mimo iż, jak sugeruje się, prezbiterium zawsze jest chrystologiczne, kaliski kościół łamie tę zasadę. Owszem wyniesienie Maryi ukazanej na malowidle w kaliskim prezbiterium jako tronującej wiąże się wprost z Jej Bożym macierzyństwem, jednakże owo macierzyństwo nie jest tutaj wyeksponowane. Matka Boża widnieje w centrum sklepienia, bez Dziecięcia, jako zasiadająca na tronie wznoszącym się na trójstopniowym podeście, a otaczają Ją ukazani na ścianach prezbiterium przedstawiciele chórów anielskich. Trójstopniowość podestu sugeruje cnoty teologalne: wiarę, nadzieję i miłość, doskonale urzeczywistnione w życiu Maryi. W pobliżu tronu Matki Bożej widnieją trzy anioły: jeden w wieńcu różanym i dwa w koronach. Towarzyszą im trzy aniołki, z których jeden trzyma złotą kadzielnicę, drugi poduszkę z sercem, a trzeci zwierciadło. Owe atrybuty odnoszą się do Jezusa Chrystusa i Jego miłości (kadzielnica) oraz do Maryi, Jej cierpienia pod krzyżem i mądrości. Kadzielnica sama w sobie stanowi symbol Zbawiciela, a zwierciadło symbolizuje - w korelacji z wezwaniem z Litanii loretańskiej - Matkę Odkupiciela ${ }^{16}$. Ponadto wspomniane atrybuty mogą także sugerować, że owe anioły są alegoriami cnót teologalnych. Co więcej, na wysokości piersi anioła, któremu towarzyszy aniołek ze zwierciadłem, widnieje otoczony promieniami trójkąt z Okiem Bożej Opatrzności, ewokujący mistyczną obecność Trójcy Świętej.

Najobficiej trynitarne alegorie i symbole obecne są w poświęconej trzem Osobom Boskim nawie. Zajmują one sklepienie i boczne ściany nawy. Owe poli-

${ }^{15}$ Por. D. Forstner, Świat symboliki chrześcijańskiej, tłum. i oprac. W. Zakrzewska, P. Pachciarek, R. Turzyński, Warszawa 2001, s. 43.

${ }_{16}$ Por. tamże, s. 441-442. Por. U. Janicka-Krzywda, Patron - atrybut - symbol, Poznań 1993, s. $217-218$. 
chromie ewokują chwałę Boga Ojca, Syna Bożego i Ducha Świętego. W centrum malowidła sklepiennego nawy widnieje Trójca Święta w scenie apoteozy świętego Franciszka z Asyżu (ilustracja 1). Bóg Ojciec wyobrażony został w trójkątnym nimbie, a Jezus Chrystus w towarzystwie anioła z trójkątem, gdzie owa trójkątność oznacza symbolicznie Trójcę Świętą. Bliżej kruchty, na sklepieniu nawy, widnieją też instrumenty muzykujących mocy anielskich, z których wydobywa się Trisagion (trzykrotne Sanctus) (por. Iz 6,3).

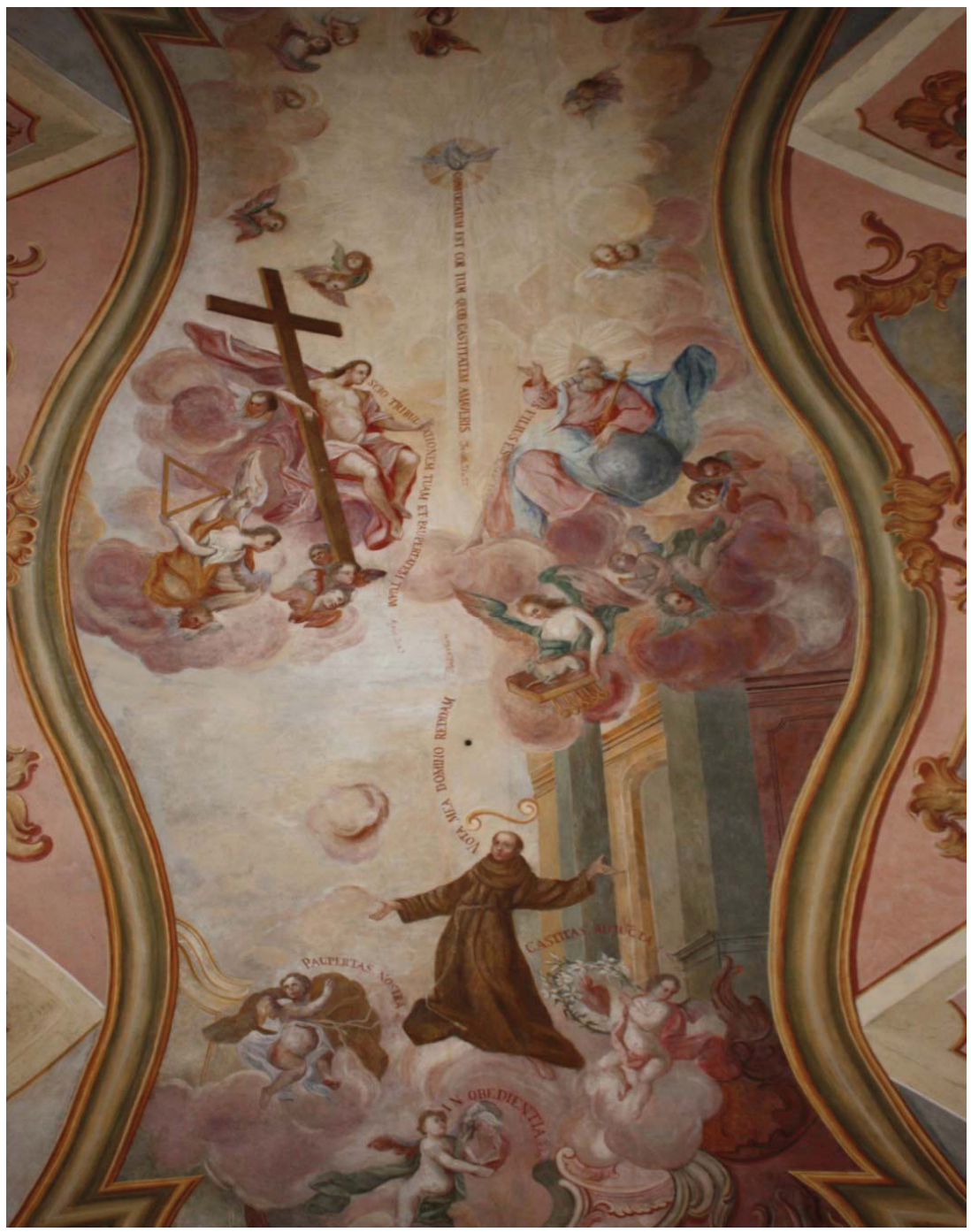

Ilustracja 1. Apoteoza świętego Franciszka z Asyżu (fot. Justyna Sprutta; dalej: J.S.) 
Trynitarna tematyka malowideł obfituje również w alegorie i emblematy rozmieszczone na żaglach i w lunetach. W nawie, na prawo od prezbiterium, pierwszy z żagli ukazuje trzech zakonników w habitach jako potrójną alegorię ascezy: z krzyżem, flagellum, włosiennicą i globusem. Kartusze zawierają następującą treść: CASTIGO CORPUS MEUM, VAE MUNDO, VADE SATANA (z łac. „Umartwiam swe ciało, biada światu, odstąp szatanie”) (por. Mt 4,10; por. Mt 18,7$)^{17}$. Na ową ascezę składają się: cielesne umartwienie (symbolizowane przez flagellum i włosiennicę), rezygnacja z ulotnych dóbr grzesznego świata (symbolizowana przez odepchnięcie globusa) oraz walka z szatanem (symbolizowana przez egzorcyzm z użyciem krzyża). Przedstawieniu towarzyszy napis: NON SECUNDUM ARMORUM POTENTIAM SED PROUT IPSI PLACET DAT DIGNIS VICTORIAM (z łac. „[Bóg] daje zwycięstwo tym, którzy są godni, nie ze względu na siłę oręża, lecz według swego upodobania"). Kolejne malowidło z żagla (centralnego) ukazuje potrójną alegorię franciszkańskiej rodziny zakonnej, dopełnioną napisami: PRIMUS CUM FRATRIBUS, PAUPERUM DOMINARUM MEDIUS, POENITENTIUM TERTIUS (z łac. „Pierwszy zakon braci, drugi pan ubogich, trzeci pokutujących") oraz: VENERUNT TRIBUS ORDINIBUS ET EXCLAMAVERUNT TUBIS ET CLAMAVERUNT IN ORATIONE ( $\mathrm{z}$ łac. „Przyszli w trzech zakonach, głośno grali na trąbach i wykrzykiwali modlitwy"). Alegorię tę stanowią: franciszkanin jako reprezentant męskiej gałęzi zakonnej, klaryska adorująca Najświętszy Sakrament jako reprezentantka żeńskiej gałęzi zakonnej oraz bogato odziana kobieta w koronie, z berłem i różańcem, reprezentująca tak zwany Trzeci Zakon Franciszkański.

Ostatni żagiel, znajdujący się na prawo od prezbiterium (sąsiadujący z kruchtą), przedstawia trzech Chronosów (ilustracja 2). Także tutaj ów pogański bóg stanowi alegorię czasu i przemijania. Warto też dodać, że zanim postrzegano Chronosa jako brodatego starca (takim ukazano go na kaliskim malowidle), wyobrażano go, zrodzonego z protogenoi, jako uskrzydlonego węża, a także, w epoce hellenistycznej, jako wysportowanego młodzieńca. Trzej starcy, widniejący na kaliskim sklepieniu, są uskrzydleni, brodaci i nadzy (okryci szatą jedynie w miejscach wstydliwych). Wyobrażeni z klepsydrami w rękach i z popadającymi w ruinę budowlami oraz z kartuszem, wskazującym na trzy wymiary czasu - przeszłość, teraźniejszość i przyszłość - zdają się wskazywać na Boga jako na Stwórcę i Pana czasu, Chronokratora. Umieszczony na kartuszu napis głosi: DEUS OMNIPOTENS QUI ES ET QUI ERAS ET QUI VENTURUS ES (z łac. „Boże wszechmogący, który jesteś, który byłeś i który przyjdziesz”) ${ }^{18}$.

17 Por. Mt 4,10.

18 Por. A. Jacyniak, Teologia wnętrza kościoła, w: 400 lat konsekracji pobernardyńskiego kościoła jezuitów w Kaliszu, red. J. Kacprzyk, A. Jacyniak, Kalisz 2007, s. 94 . O ewolucji wizerunku Chronosa: por. M. Siekierka, Czas a wybrane aspekty jego ujmowania w kulturze antycznych sym- 


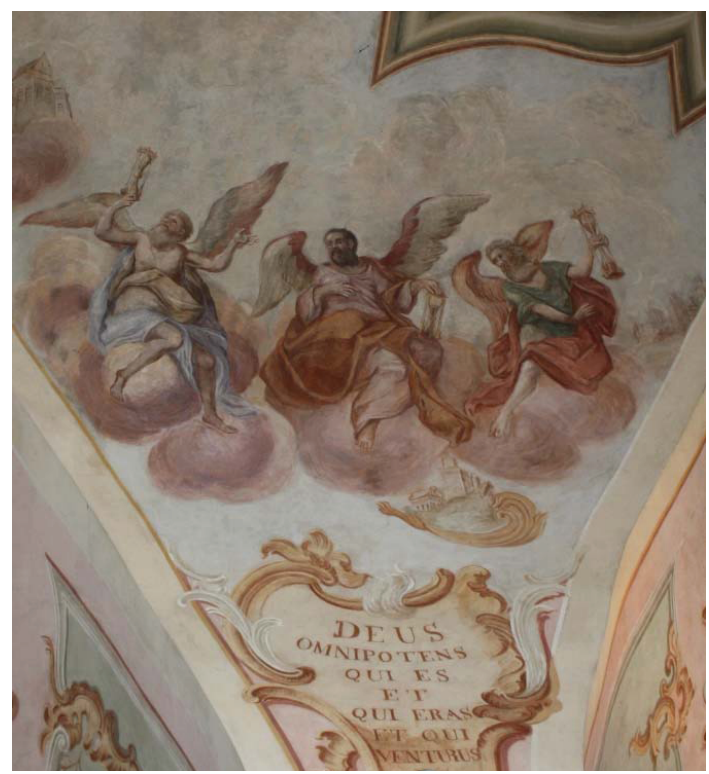

Ilustracja 2. Alegoria Czasu (fot. J. Sprutta)

Po przeciwnej stronie kościoła widnieją na pierwszym żaglu (od strony prezbiterium) kobiece alegorie cnót teologalnych (ilustracja 3), a towarzyszy im

boli oraz filozofii starożytnej Grecji okresu przedsokratejskiego, „Pisma Humanistyczne” (2014) z. 12, s. 21. Skrzydła u ramion Chronosa akcentują jego wyższość, a nawet boskość, i dowodzą nieodwracalności działania Czasu. Efekt jego działania ukazują zdruzgotane, zniszczone, obalone „bez trudu i znużenia”, towarzyszące Chronosom budowle. Natomiast klepsydra symbolizuje uskrzydlona lub pozbawiona skrzydeł - ulotność, czyli przemijanie czasu. Por. tamże, s. 19. Por. C. Ripa, Ikonologia, tłum. I. Kania, Kraków 1998, s. 238-239. Por. K. Moisan-Jabłońska, ,, Mors et purgatorium”. Ikonografia dwóch obrazów z kościoła p.w. Świętego Ducha w Lublinie, „Saeculum Christianum" (1995) nr 2, s. 110. Por. tamże, s. 113. Por. J. Seibert, Leksykon sztuki chrześcijańskiej. [Tematy, postacie, symbole], thum. D. Petruk, Kielce 2007, s. 154. Por. M. Siekierka, Czas a wybrane aspekty jego ujmowania w kulturze antycznych symboli oraz filozofii starożytnej Grecji okresu przedsokratejskiego, s. 19. Por. K. Balbuza, Personifikacja „Aeternitas” na monetach rzymskich propagujących ideę wieczności cesarza, „Studia Europea Gnesnensia” t. VIII (2013), s. 26; J. Nowiński, Nagrobek opata-mecenasa Mikołaja Antoniego Lukomskiego w pocysterskim kościele w Lązie nad Warta, „Biuletyn Historii Sztuki” (2008) nr 3-4, s. 385, 403; J. Sito, Barokizacja wystroju katedry przemyskiej za rządów Aleksandra Antoniego Fredry, Przemyśl 1992, s. 11, 25. Jednakże można przyjąć, że ani poznański projektodawca, ani też bernardyński wykonawca kaliskich malowideł o tematyce trynitarnej nie dostrzegał antycznych (z okresu postsokratejskiego) protoplastów Trójcy Świętej. O dalszej analogii można natomiast mówić, odnosząc kaliskie Chronosy do znanej z rzymskich monet personifikacji Aeternitas. Zatem należałoby stwierdzić, że mimo odległej analogii, antyczne figury i symbole nie stanowiły bezpośredniej wykładni uwzględniającego autorytet jezuickiego teologa bernardyńskiego malarstwa potrydenckiego w Kaliszu. 


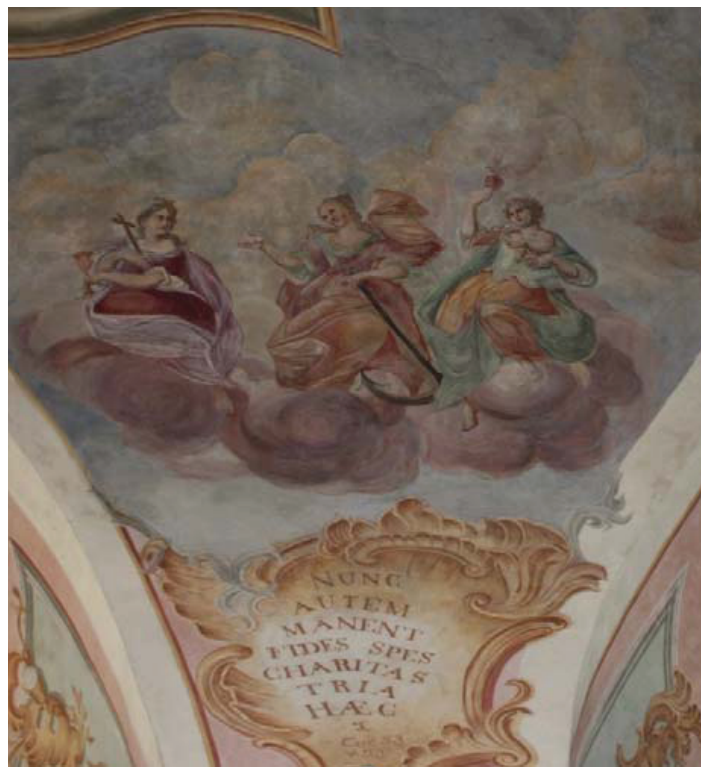

Ilustracja 3. Alegorie cnót teologalnych (fot. J.S.)

napis: NUNC AUTEM MANENT FIDES, SPES, CHARITAS TRIA HAEC (z łac. „Teraz więc trwają wiara, nadzieja i miłość, te trzy”) (por. 1 Kor 13,13). Wiarę W. Żebrowski przedstawił z krzyżem i kielichem eucharystycznym, nadzieję z kotwicą, a miłość z sercem gorejącym.

Kolejny żagiel ewokuje troistość prawa, czyli potrójne jego oblicze (ilustracja 4). Malowidło ukazuje młodzieńca $z$ tondem na piersi, zawierającym napis NATURA MIHI LEX (z łac. „Natura jest mi prawem”), a wskazującym na zapisane w sercu prawo naturalne. Widnieje też tutaj Mojżesz z tablicami Dziesięciorga Przykazań jako prawem Dekalogu oraz młodzieniec z księgą Ewangelii, wskazujący na prawo Nowego Przymierza. W tym kontekście Bóg jawi się jako wyrokujący Prawodawca, o czym mówi dopełniający przedstawienie napis: UNUS EST LEGISLATOR ET IUDEX QUI POTEST PERDERE ET LIBERARE (z łac. ,Jeden jest Prawodawca i Sędzia, który może skazywać i uniewinniać"). Z tym przedstawieniem sąsiaduje przedstawienie ilustrujące moralną rozterkę. Opatrzone napisem poniekąd nieodpowiadającym treści: UNUS DEUS OMNIUM QUI EST SUPER OMNES ET PER OMNIA ET IN OMNIBUS NOBIS (z łac. ,Jeden Bóg wszystkich, który jest ponad wszystkimi, poprzez wszystko i w nas wszystkich"), ukazuje młodzieńca stającego przed dylematem: czy wybrać dobro duchowe, skutkujące świętością, czy pełne pokus dobro materialne? Alegorią pierwszego z nich jest kobieta $\mathrm{z}$ lilią $\mathrm{w}$ ręku, a drugiego kobieta z kosztownościami i monetami. 


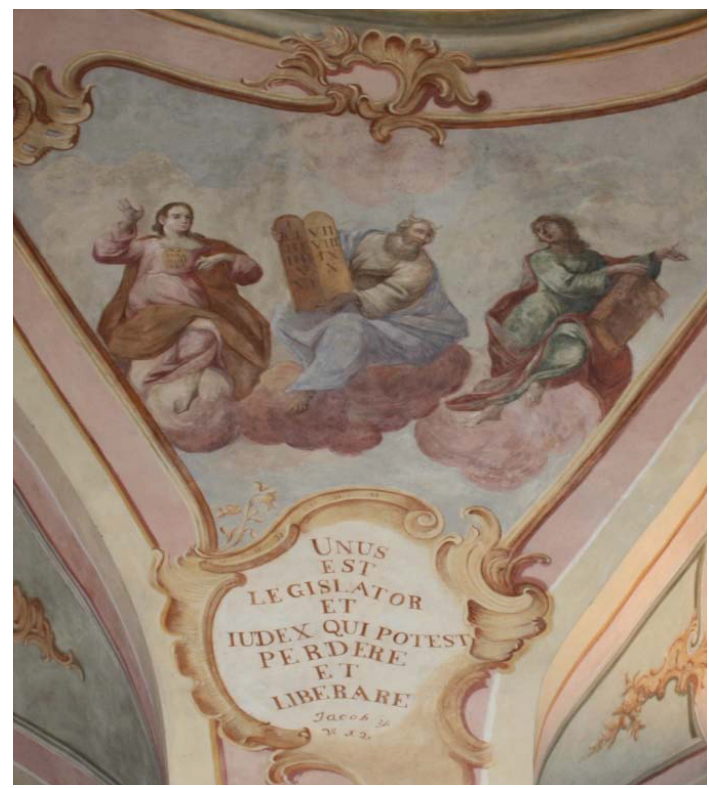

Ilustracja 4. Alegorie prawa (fot. J.S.)

Najniżej w hierarchii symbolicznej ważności w przestrzeni sakralnej sytuują się - rozmieszczone w lunetach - emblematy. Analogicznie do przedstawień z żagli również one dopełniają, wzbogacając niebagatelną treścią, główne, usytuowane na sklepieniu przedstawienie. Częściowo przybliżają sam dogmat o Trójcy Świętej, a częściowo Jej przymioty.

Zawieszonej nad wzburzonym morzem kotwicy (ilustracja 5) o trzech zakończeniach towarzyszy napis: ULTIMUM REFUGIUM (z łac. „Ostateczne schronienie"), wskazując na Boga jako port zbawienia i definitywny cel owej „ucieczki”.

Wyłaniająca się z obłoku manus Dei kreśli cyrklem (ilustracja 6) na pergaminie trzy zachodzące na siebie okręgi, ewidentnie ewokując dogmat o Trójcy Świętej, a towarzyszy temu napis: TRIUM OMNIMODA PARITAS (z łac. „Bezwzględna równość Trzech”).

Imię „Światło” w odniesieniu do Trójcy Świętej zawiera napis: LUX TERNA ET UNUM (z łac. „Światło potrójne i jedno”), a jego symbolem jest antropomorfizowane słońce (ilustracja 7) o tarczy symbolizującej naturę boską, z trzema wiązkami promieni, oznaczającymi trzy Osoby Boskie, czyli ich zróżnicowaną, osobową tożsamość Ojca, Syna i Ducha Świętego.

Natomiast trójramiennemu lichtarzowi (ilustracja 8) z trzema palącymi się świeczkami towarzyszy napis: UNUS IN SUBSTANTIA (z łac. „Współistotny”), uwypuklający jeden $\mathrm{z}$ aspektów dogmatu: równość $\mathrm{w}$ bóstwie, czyli w natu- 
rze boskiej. Malowidła z lunet przybliżają też przymioty Trójcy Świętej, co już wcześniej wzmiankowano. Miłosierdzie trzech Osób Boskich ilustrują trzy dłonie z monetami, kierujące się ku wyciągającemu proszalnie rękę żebrakowi. Przedstawienie to dopełnia napis: AEQUALIS MISERICORDIA TRIUM (z łac. „Jednakowe miłosierdzie Trzech”).

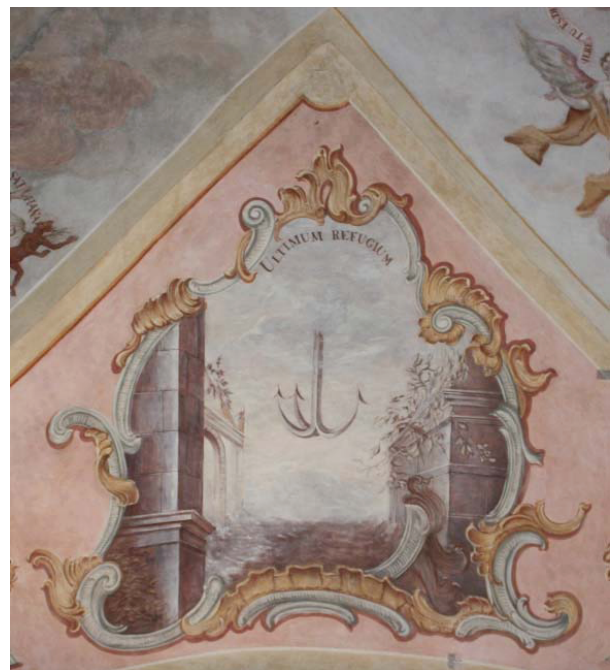

Ilustracja 5. Kotwica (fot. J.S.)

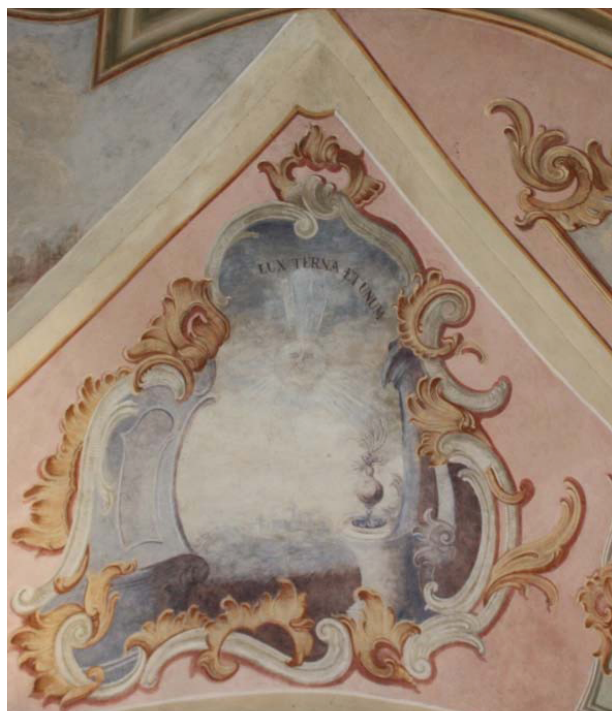

Ilustracja 7. Stońce (fot. J.S.)

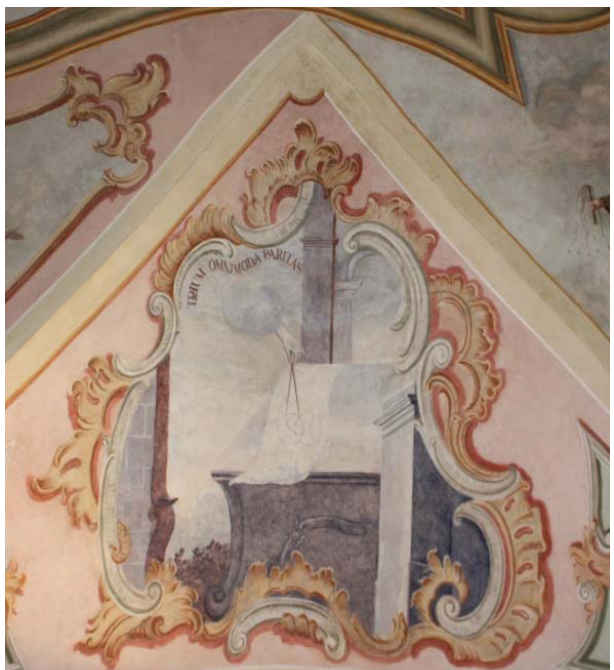

Ilustracja 6. Cyrkiel (fot. J.S.)

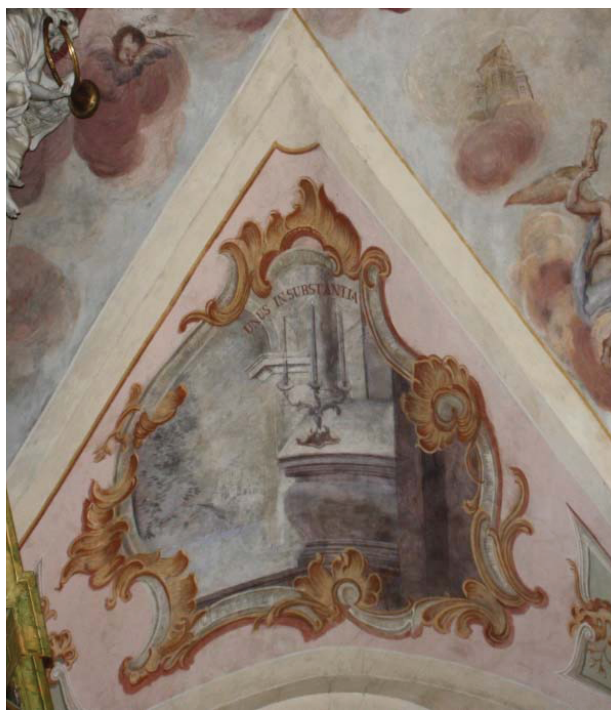

Ilustracja 8. Lichtarz (fot. J.S.) 


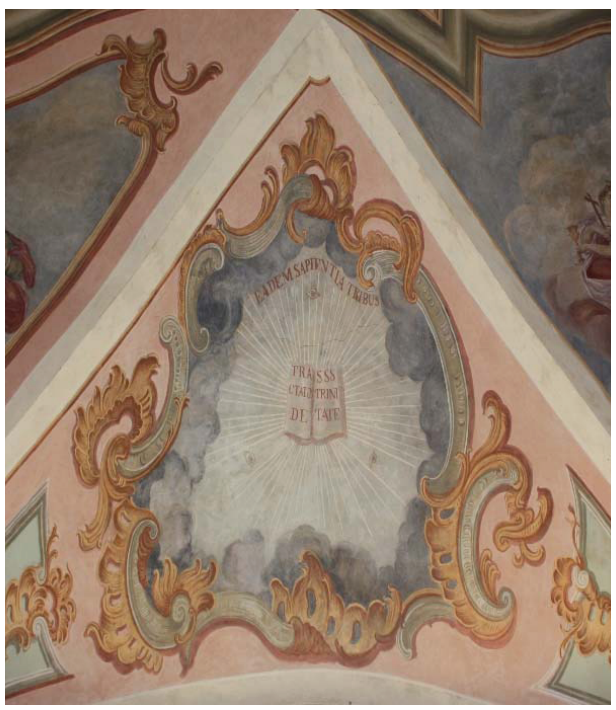

Ilustracja 9. ,,Traktato Trójcy Przenajświętszej” (fot. J.S.)

O mądrości Boga Trójjedynego mówi natomiast napis: EADEM SAPIENTIA TRIBUS (z łac. „Ta sama mądrość Trzech”), towarzyszący wyobrażonej w płomieniach księdze będącej Tractatus de SSS Trinitate (z łac. „Traktatem o Trójcy Przenajświętszej”) z trójkątem z trojgiem oczu, gdzie trzykrotne „S” oznacza trzy Osoby Boskie. Ostatni przymiot Boga, czyli troiste piękno, ewokuje stojący na postumencie wazon $\mathrm{z}$ rośliną o trzech kwiatach tudzież napis: PAR TRIUM PULCHRITUDO (z łac. „Równe jest piękno Trzech”). Na opatrzność Bożą (łac. providentia Dei) wskazuje przedstawienie z kościołem w centrum, ukazujące zwieńczony krzyżem globus, podtrzymywany przez Boga trzema palcami jednej ręki. To malarska wizja pieczy sprawowanej przez Trójcę Świętą nad światem, dopełniona komentarzem: TER UNA TENET (z łac. „Jedną ręką potrójnie trzyma").

Z owych malowideł W. Żebrowskiego wyłania się Trójca Święta między innymi: obdarzająca prawem, zarządzająca czasem, powołująca stany, doceniająca ascezę, okazująca miłosierdzie, bogata w mądrość, udzielająca jasności w rozeznaniu właściwego wyboru, absolutnie piękna czy też troszcząca się o stworzenie i podtrzymująca je w istnieniu: Bóg będący ad intra i zarazem ad extra.

Niniejszy artykuł jest jedynie przyczynkiem do naukowej refleksji nad dosłownym i symbolicznym przedstawianiem dogmatu trynitarnego w sztuce, na podstawie kaliskiej polichromii W. Żebrowskiego. Najprawdopodobniej autorem jej projektu (lub samych napisów) jest poznański jezuita A. Kiełbasie- 
wicz ${ }^{19}$, lecz o jego dorobku obecnie prawie nic nie wiadomo. W. Żebrowski inspirował się teologicznymi sugestiami owego jezuity, ale ciągle pozostaje kwestią nierozstrzygniętą, czy wkład A. Kiełbasiewicza polegał na stworzeniu projektów polichromii, czy jedynie na zaprojektowaniu tekstów dopełniających kaliskie malowidła? ${ }^{20}$. Z pewnością program, w którym liczba „trzy” odgrywa istotną rolę jako wyrażająca dogmat trynitarny i trynitarną rzeczywistość, miał odpowiadać zamiarowi poświęcenia nawy kaliskiego kościoła chwale Trójcy Świętej.

Kaliska polichromia jako potrydencka wręcz domaga się ujętej chociażby marginalnie prawdy o Trójcy Świętej, wyłaniającej się z zaleceń obradującego w latach 1545-1563 Soboru Trydenckiego. Jest to Trójca Święta udzielająca się ad extra. Trynitarna myśl Tridentinum koncentruje się na dziele Jezusa Chrystusa, jakim jest dokonane na Golgocie usprawiedliwienie skutkujące łaską czyniącą sprawiedliwym ${ }^{21}$. Sprawiedliwością obdarza, za pośrednictwem drugiej Osoby Boskiej, Bóg Ojciec, a przyjęcie usprawiedliwiającej łaski uprzedzającej dokonuje się w Duchu Świętym. Odpowiedzią na ten dar staje się łączona z pokutą, ufnością, nadzieją, zakorzeniona w miłosiernej miłości Trójcy Świętej metanoia $^{22}$. Chwała Boga Ojca i Syna Bożego, życie wieczne, Bóg Ojciec jako pełen miłości miłosiernej, obmywający, uświęcający, naznaczający i namaszczający, Syn Boży jako wynagradzający za winy grzesznej ludzkości i wysługujący jej usprawiedliwienie, gwarantujący to usprawiedliwienie sakrament chrztu, czyli sakrament wiary, tudzież czyniąca sprawiedliwym i odnawiająca w rozlewającym w sercach łaskę i miłość Bożą Duchu Świętym Boża sprawiedliwość jawi się tutaj jako przyczyna usprawiedliwienia ${ }^{23}$. Usprawiedliwiając, Trójca Święta obdarza cnotami teologalnymi, czyli wiarą, nadzieją i miłością ${ }^{24}$. Trydencka idea Trójcy Świętej, wynikająca zwłaszcza z nauki Tridentinum o usprawiedliwieniu, uwydatnia między innymi usprawiedliwiającą Ofiarę Jezusa Chrystusa na Golgocie i jej owoce, wartość cnót teologalnych, miłość miłosierną Boga do grzesznika oraz Jego drogę ku Bogu, będącą drogą na przykład pokuty i ascezy, co też znalazło swoje odzwierciedlenie w polichromii kościoła pobernardyńskiego w Kaliszu.

19 Por. Veni, vidi, vici, http://kaliszobranie.blogspot.com/2014/03/veni-vidi-vici.html [dostęp 20.05.2021]. Por. S. Szymański, Dzieje klasztoru pobernardyńskiego w Kaliszu, obecnie jezuitów, s. 52. Por. M. Walczak, Architektoniczna perta Kalisza. [Kościót i klasztor księży jezuitów w Kaliszu], s. 17-27.

${ }^{20}$ Por. W. Kościelniak, Kościół pobernardyński oo. jezuitów. Krzyż od ognia, cz. 1, http:// www.info.kalisz.pl/szkic/29.htm [dostęp 20.05.2021].

${ }^{21}$ Por. Breviarium fidei. Wybór doktrynalnych wypowiedzi Kościoła, oprac. I. Bokwa, T. Gacia, S. Laskowski, H. Wójtowicz, Poznań 2007, III, 317; Dokumenty Soborów Powszechnych. [Lateran V, Trydent, Watykan I], oprac. A. Baron, H. Pietras, t. IV, cz. 1, Kraków 2007.

${ }_{22}$ Por. Breviarium fidei. Wybór doktrynalnych wypowiedzi Kościoła, V, 319; VI, 326.

${ }^{23}$ Por. tamże, VII, 321.

${ }^{24}$ Por. tamże, VII, 322. 


\section{Trinitologia picta on the Example of Polychromy in the Church of the Visitation of the Blessed Virgin Mary in Kalisz Research Programme}

\section{Summary}

The polychrome of the Bernardine church in Kalisz (now the Jesuit church) is rich in Trinitarian themes. Trinitarian motifs and symbols are presented most abundantly in the nave. The wall paintings of the presbytery and the nave painted by brother Walenty Żebrowski, Bernardine. These paintings are from the late Baroque. The polychrome of Kalisz is the last work of this Bernardine. W. Żebrowski worked not only in Kalisz, but also for the Bernardine churches in Poznań, Kadyny, Wschowa, Skępe, Warta, Ostrołęka, Warszawa and probably in Owińska, Ostrzeszów and maybe in Łęczyca too. He was particularly famous as a landscapist. Although the article shows Trinitarian motifs and symbols on the wall paintings in the Bernardine church in Kalisz, it also shows the artistic activity of W. Żebrowski in the mentioned big and small towns and villages.

\section{Keywords}

Baroque, Bernardines, Kalisz, polychrome, Walenty Żebrowski

\section{Słowa kluczowe}

barok, bernardyni, Kalisz, polichromia, Walenty Żebrowski

\section{Bibliografia}

Balbuza K., Personifikacja „Aeternitas” na monetach rzymskich propagujacych idee wieczności cesarza, „Studia Europea Gnesnensia” t. VIII (2013), s. 7-27.

Breviarium fidei. Wybór doktrynalnych wypowiedzi Kościoła, oprac. I. Bokwa, T. Gacia, S. Laskowski, H. Wójtowicz, Poznań 2007.

Czerwińska A.E., Adama Swacha portret własny - czyli kilka uwag o sygnaturach i autoportretach barokowego artysty, http://www.lad.pl/assets/czerwinska_swach.pdf [dostęp 16.05.2021].

Dokumenty Soborów Powszechnych. [Lateran V, Trydent, Watykan I], oprac. A. Baron, H. Pietras, t. IV, cz. 1, Kraków 2007.

Dymkowska J.A., Historia pobernardyńskiego zespołu klasztornego w Kaliszu (obecnie klasztor oo. Jezuitów), „Kalisia Nowa” (2007) nr 2-3-4, s. 8-9.

Dymkowska J.A., Kościół pobernardyński (obecnie OO. Jezuitów), http://www.kalisz. info/kosciol-jezuitow.html [dostęp: 20.05.2021].

Forstner D., Świat symboliki chrześcijańskiej, tłum. i oprac. W. Zakrzewska, P. Pachciarek, R. Turzyński, Warszawa 2001. 
Jacyniak A., Teologia wnętrza kościoła, w: 400 lat konsekracji pobernardyńskiego kościoła jezuitów w Kaliszu, red. J. Kacprzyk, A. Jacyniak, Kalisz 2007, s. 92-102.

Jaksim-Kirejczyk P., Pierwowzory graficzne dziewięciu chórów anielskich na freskach Walentego Żebrowskiego w Warcie, w: Inspiracje grafika europejska w sztuce polskiej. [Czasy nowożytne], red. K. Moisan-Jabłońska, K. Ponińska, Warszawa 2010, s. 159-170. Janicka-Krzywda U., Patron - atrybut - symbol, Poznań 1993.

Jank T., Życie i twórczość malarska brata Adama Swacha (1668-1747), Kraków 2017.

Jusiak O.R., Bernardyńskie sanktuaria w Polsce, file://C:/Users/PC/Downloads/Oktawian_Roman_Jusiak_OFM_2005_Bernardynskie_sanktuaria_w_Polsce\%20(1).pdf [dostęp 16.05.2021].

Karpowicz M., Piękne nieznajome. Warszawskie zabytki XVII i XVIII wieku, Warszawa 1986.

Kościelniak W., Kościót pobernardyński oo. jezuitów. Krzyż od ognia, cz. 1, http://www. info.kalisz.pl/szkic/29.htm [dostęp 20.05.2021].

Kowalczyk J., Andrea Pozzo a późny barok w Polsce. Freski sklepienne, cz. 2, „Biuletyn Historii Sztuki” (1975) nr 4, s. 335-350.

Kurzej M., Ikonografia malowidet w zakrystii (tzw. skarbcu) kościoła Dominikanów w Krakowie, w: Sztuka w kręgu krakowskich dominikanów, red. A. Markiewicz, M. Szyma, M. Walczak, Kraków 2013, s. 787-811.

Moisan-Jabłońska K., „, Mors et purgatorium”. Ikonografia dwóch obrazów z kościoła p.w. Świętego Ducha w Lublinie, „Saeculum Christianum” (1995) nr 2, s. 105-119.

Mulczyńska-Pawlak A., Malarska działalność Walentego Żebrowskiego, „Studia Muzealne" (1968) nr 6, s. 103-123.

Nowiński J., Nagrobek opata-mecenasa Mikołaja Antoniego Łukomskiego w pocysterskim kościele w Ladzie nad Warta, „Biuletyn Historii Sztuki” (2008) nr 3-4, s. 385-406.

Poniedziałek E., Walczak M., Materialny i duchowy wymiar obecności Zakonu Jezuitów w Kaliszu, w: Dziedzictwo kulturowe Miasta Kalisza i regionu południowej Wielkopolski, red. S. Kowalska, Poznań-Kalisz 2013, s. 9-25.

Ripa C., Ikonologia, tłum. I. Kania, Kraków 1998.

Seibert J., Leksykon sztuki chrześcijańskiej. [Tematy, postacie, symbole], thum. D. Petruk, Kielce 2007.

Siekierka M., Czas a wybrane aspekty jego ujmowania w kulturze antycznych symboli oraz filozofii starożytnej Grecji okresu przedsokratejskiego, „Pisma Humanistyczne” (2014) z. 12, s. 17-36.

Sito J., Barokizacja wystroju katedry przemyskiej za rządów Aleksandra Antoniego Fredry, Przemyśl 1992.

Sprutta J., Barokowa polichromia kościoła pobernardyńskiego w Kaliszu, „Studia Franciszkańskie" t. XXVII (2017), s. 265-295.

Szymański S., Dzieje klasztoru pobernardyńskiego w Kaliszu, obecnie jezuitów, w: 400 lat konsekracji pobernardyńskiego kościoła jezuitów w Kaliszu, red. J. Kacprzyk, A. Jacyniak, Kalisz 2007, s. 49-69. 
Tabaka A., Władca pędzla w habicie, „Kalisia Nowa” (2007) nr 2-3-4, s. 1.

Tomczak S.B., Biblioteka Gtówna Prowincji św. Franciszka z Asyżu zakonu Braci Mniejszych w Poznaniu, „Forum Bibliotek Medycznych” (2017) nr 1, s. 282-340.

Veni, vidi, vici, http://kaliszobranie.blogspot.com/2014/03/veni-vidi-vici.html [dostęp 20.05.2021].

Walczak M., Architektoniczna perła Kalisza. [Kościól i klasztor księży jezuitów w Kaliszu], „Studia Pedagogiczno-Artystyczne” t. III (2003), s. 17-27.

Witwińska M., Dzieje warszawskiej polichromii Walentego Żebrowskiego, „Biuletyn Historii Sztuki" (2006) nr 1, s. 59-94.

Witwińska M., Ostrołęcka polichromia Walentego Żebrowskiego, „Biuletyn Historii Sztuki” (1970) nr 3-4, s. 245-260.

Witwińska M., Polichromia dwóch Trójc w kościele p.w. św. Józefa we Wschowie, „Ochrona Zabytków” (1999) nr 3, s. 264-279.

Zdziarska R., Malowidła ścienne w kościele św. Anny w Warszawie i ich konserwacja, „Ochrona Zabytków” (1989) nr 3-4, s. 207-237. 